Open Access

\title{
Educational Action Research and Triple Helix principles in entrepreneurship education: introducing the EARTH design to explore individuals in Triple Helix collaboration
}

\author{
Michael Mandrup* (i) and Tine Lynfort Jensen
}

* Correspondence:
mmandrup@sdu.dk
Institut for Sprog og
Kommunikation, Syddansk
Universitet (Department of
Language and Communication,
University of Southern Denmark),
Campusvej 55, 5230 Odense M,
Denmark

* Correspondence: mmandrup@sdu.dk Universitet (Department of Language and Communication, Campusvej 55,5230 Odense M

\begin{abstract}
This article presents a practical approach on how to develop and explore an educational design combining Triple Helix theory and Educational Action Research for support of student learning and innovation activities in interaction with various actors. The design, termed EARTH, organizes systemic interactions between selected sectoral actors at the level of individuals in a context of innovative learning. Educational Action Research and Triple Helix theory share common principles seeking to generate change through collaboration, co-creation, equality, voluntarism, communication, and consensus-making between various actors. This creates a productive framework for supporting students' innovation activities and learning experiences, educational research, and organizational development. The EARTH design provides a basis for open innovation projects between students, teachers, researchers, and external partners from different sectors. Research data indicate that Triple Helix dynamics of substitution support students' competence and project developments. The design generates real-world innovation and entrepreneurship experiences for the students through mastery, social change, and vicarious learning. Furthermore, student teams organize self-initiated project interactions with diverse sectoral actors. The principles of Educational Action Research and Triple Helix are ideals that may be difficult to align due to asymmetries between involved partners unless such structural deficiencies are mutually addressed. This may be corrected by reorganizing the relations between Triple Helix spaces of knowledge, innovation, and consensus. The article concludes with a discussion of combining Educational Action Research with Triple Helix theory and some general perspectives for future developments of the EARTH design.
\end{abstract}


摘要

本文提出如何开发和探索一种实用方法, 将三螺旋理论和教育行动研究结合起来 的一个教育设计，以支持学生在与各种主体互动中的学习和创新活动。我们把这 一设计称为“EARTH”。在创新学习背景下, 在个人层次上,EARTH 设计组织在确定部 门主体之间的系统的相互作用。教育行动研究与三螺旋理论有着共同的原则,即 寻求通过不同利益主体之间的合作、共同创造、平等、自愿、沟通和共识产生 变化。这为支持学生的创新活动和学习经验、教育研究和组织发展创造了一个 富有成效的框架。EARTH设计为在学生、教师、研究人员和来自不同部门的外部 合作伙伴之间的开放创新项目提供了基础。

研究结果表明:三螺旋替代动力支持学生的能力和项目开发。这一设计通过控 制、社会变革和替代学习为学生生成在真实世界里的创新和创业经验。此外，学 生团队与不同部门主体一起组织自启动项目的相互作用。教育行动研究和三螺 旋的原则是理想的,因为在合作伙伴之间的不对称可能难以摆平,除非这种结构性 缺陷是相互解决的。这可以通过重新组织知识、创新和共识三个三螺旋空间之 间的关系来加以纠正。本文最后以将教育行动研究与三螺旋理论结合的讨论以 及关于EARTH设计的未来发展的某些普遍观点结尾。 


\section{Résumé}

Cet article présente une approche pratique sur la façon de développer et d'explorer un projet éducatif combinant la théorie de la Triple Hélice et la recherche-action éducative pour soutenir les activités d'apprentissage et d'innovation des étudiants en interaction avec divers acteurs. Le projet nommé EARTH, organise des interactions systémiques entre des acteurs sectoriels sélectionnés au niveau des individus dans un contexte d'apprentissage innovant. La recherche-action éducative et la théorie de la Triple Hélice partagent des principes communs visant à générer le changement par la collaboration, la co-création, l'égalité, le volontarisme, la communication et la concertation entre les différents acteurs. Elles créent un cadre productif pour accompagner les activités d'innovation et les expériences d'apprentissage, la recherche éducative et le développement organisationnel des étudiants. Le projet EARTH établit une base pour des projets ouverts d'innovation entre les étudiants, les enseignants, les chercheurs et les partenaires externes de différents secteurs.

Les données collectées indiquent que les dynamiques de substitution de la Triple Hélice appuient les développements de compétences et de projets des étudiants. Le projet génère des expériences d'innovation et d'entrepreneuriat de la vie réelle pour les étudiants grâce à la maîtrise, au changement social et à l'apprentissage indirect. De plus, les équipes d'étudiants organisent des interactions de projet auto-initiées avec divers acteurs sectoriels. Les principes de la recherche-action éducative et de la Triple Hélice sont des idéaux qui peuvent être difficiles à suivre en raison d'asymétries entre les partenaires impliqués, à moins que ces déficiences structurelles ne soient corrigées mutuellement. Cela peut être corrigé par la réorganisation des relations entre les cercles du savoir, de l'innovation et de consensus de la Triple Hélice. L'article se termine par une discussion sur la combinaison de la recherche-action éducative avec la théorie de la Triple Hélice et quelques perspectives générales pour les développements futurs du projet EARTH. 


\section{Resumo}

Este artigo apresenta uma abordagem prática sobre como desenvolver e explorar um projeto educacional combinando a teoria da Hélice Tríplice e a Pesquisa-Ação para apoiar atividades de aprendizado e inovação de estudantes em interação com vários atores. O design, denominado EARTH, organiza interações sistémicas entre atores setoriais selecionados ao nível dos indivíduos sem um contexto de inovação na aprendizagem. A Pesquisa-Ação e a teoria da Hélice Tríplice compartilham princípios comuns buscando gerar mudanças por meio da colaboração, co-criação, igualdade, voluntarismo, comunicação e consenso entre os diversos atores. Isso cria uma estrutura produtiva para apoiar as atividades inovadoras dos estudantes, experiências de aprendizagem, pesquisa educacional e desenvolvimento organizacional. O design do projeto EARTH fornece uma base para projetos de inovação aberta entre estudantes, professores, pesquisadores e parceiros externos de diferentes setores. Os dados da pesquisa indicam que a dinâmica de substituição da Triple Helix apóia as competências e a evolução dos projetos dos alunos. $O$ projeto gera experiências de inovação e empreendedorismo do mundo real para os alunos através do domínio, da mudança social e da aprendizagem indireta.

Além disso, as equipes estudantis organizam interações de projetos iniciados pelo próprios grupos com diversos atores setoriais. Os princípios da Pesquisa-Ação e da Hélice Tríplice são ideais que podem ser difíceis para alinhar devido a assimetrias entre os parceiros envolvidos, a menos que tais deficiências estruturais sejam abordadas mutuamente. Isso pode ser corrigido pela reorganização das relações entre os espaços de conhecimento, inovação e consenso da Hélice Tríplice. O artigo conclui com uma discussão sobre a combinação de Pesquisa-Ação com a teoria da Hélice Tríplice e com algumas perspectivas gerais para futuros desenvolvimentos do design do projeto da EARTH. 
Palavras-chave: HéliceTríplicePesquisa-Açãolnovação e EmpreendedorismoEstudantes

Аннотация: В настоящей статье представлен практический подход к развитию и изучению образовательной модели, совмещающей теорию Тройной спирали и исследовательские инициативы в образовании в целях поддержки познавательных и инновационных инициатив студентов в различных группах. Модель, названная EARTH, обеспечивает систематическое взаимодействие между выбранными группами на уровне индивидов. Исследовательские инициативы в образовании и Теорию тройной спирали объединяют общие принципы поиска точек для реализации изменений через сотрудничество, творчество, равенство, добровольность, коммуникации и поиск консенсуса между различными участниками. Это создает продуктивную модель для поддержки студенческих инновационных инициатив и познавательного процесса, научных исследований и организационного развития. Модель EARTH формирует основу для открытых инновационных проектов между студентами, преподавателями, учеными и внешними партнерами из различных секторов. Результаты исследований указывают на динамику поддержки студенческих знаний и проектных разработок в Тройных спиралях. Модель позволяет генерировать актуальные инновации и предпринимательские инициативы в студенческой среде через получение дополнительных прикладных знаний и социальных навыков. Кроме того, студенческие команды формируют независимые проектные взаимодействия с представителями различных отраслей. Принципы исследовательских инициатив в образовании и Тройная спираль являются идеальным примером того, какие сложность могут возникать в управлении асимметричными группами участников и сохраняться до тех пор, пока большинство структурных различий нивелируется. Это может быть скорректировано путем реорганизации взаимосвязей в Тройной спирали в области знаний, инноваций и консенсуса. В конце статьи приведено обсуждение потенциала комбинации исследовательских инициатив в образовании с Теорией тройной спирали и некоторых будущих перспектив модели ЕАRTH. 


\section{Resumen}

Este artículo presenta un enfoque práctico sobre cómo desarrollar un diseño educativo que combine la teoría de Triple Hélice y la Investigación de Acción Educativa. El diseño, denominado EARTH, organiza interacciones entre actores sectoriales en un contexto de aprendizaje innovador. Investigación de Acción Educativa y la teoría de Triple Hélice comparten principios comunes que buscan generar cambios a través de la colaboración, la co-creación, la igualdad, el voluntarismo, la comunicación y la creación de consensos entre varios actores. Esto crea un marco productivo para apoyar las actividades y experiencias de los estudiantes, la investigación educativa, y el desarrollo organizacional. El diseño EARTH proporciona una base para proyectos de innovación abierta entre estudiantes, profesores, investigadores y socios externos de diferentes sectores.

Nuestra investigación muestra que la dinámica de sustitución de la Triple Hélice respalda la competencia de los estudiantes y el desarrollo de proyectos. El diseño genera experiencias de emprendimiento en el mundo real para los estudiantes a través del dominio de contenidos, del cambio social, y del aprendizaje vicario. Además, los equipos de estudiantes organizan interacciones de proyectos autoiniciados con diversos actores sectoriales. Los principios de la Investigación de Acción Educativa y la Triple Hélice son ideales que pueden también ser difíciles de reconciliar debido a las asimetrías entre los participantes.

El artículo concluye con una discusión de la combinación de la Investigación de Acción Educativa con la teoría de Triple Hélice y algunas perspectivas generales para el desarrollo futuro del diseño EARTH.

Keywords: Triple Helix, Educational Action Research, Innovation and Entrepreneurship Education, Students

关键词 三螺旋教育行动研究创新创业教育学生

Mots clés Triple HéliceRecherche-action éducativeInnovation et Formation à l'EntrepreneuriatEtudiants

Кмючевые слова Тройная спирахьИсследовательские инициативы в образованииИнновационное и преАпринимательское образованиестуденты

Palabras clave Triple HéliceInvestigación de Acción EducativaInnovación y EmprendimientoEstudiantes

\section{Multilingual abstract}

Please see Additional file 1 for translation of the abstract into Arabic.

\section{Introduction}

This article presents an Educational Action Research approach to implement the Triple Helix framework in an educational setting for teaching innovation and entrepreneurship. We term this approach "EARTH" (Educational Action Research and Triple Helix). The design title signals an integrative approach to university education enabling collaboration between students, teachers, researchers, and external actors in order to develop better programs of support for student's innovation activities through social, entrepreneurial, 
and innovative learning experiences. With this introduction of EARTH, we address the following research questions: (1) how may university education integrate Triple Helix collaboration for support of students' learning and students' contribution to innovation? (2) Who are the key actors involved? (3) What theoretical framework approach may provide both means to construct and to research these relations within an educational setting?

First, we set out with a description of the development of higher education towards entrepreneurialism. Next, we outline the theoretical foundation of the EARTH design and position our novel approach within the field of entrepreneurship education. Hereafter, the context of the course and the methodology for the EARTH design are described. The following two sections cover selected research results and discussion. Further, perspectives on implementation and recommendations conclude the article and position the EARTH design within the research field of Triple Helix. This paper presents a work in progress with the purpose of providing a practical example of how the Triple Helix can be contextualized and incorporated into education for innovation and entrepreneurship. Future work will provide complete evaluations of the EARTH approach.

\section{The changing role of university towards entrepreneurialism}

In recent years, an intensified political and industrial focus on the economic outcomes of academic knowledge has emerged with increasing demands on universities to reform institutional practices and to assess the relevancy of research and education for society at large. Academia thereby faces the task of integrating the traditional first and second missions of the university with third mission objectives such as applied research, technology transfer, and knowledge-based innovation and entrepreneurship as drivers for economic growth. Universities are changing from being "autonomous institutions to service providers accountable to the interests of multiple stakeholders" including government, employers, students, staff, private companies, and regional bodies (Mann 2008, Shattock 2009). A new universal model is emerging as a consequence and thereby changing the role of the 'university' towards a new paradigm of entrepreneurialism and innovation (Etzkowitz et al. 2000), which in some cases develop into the realized vision of "the entrepreneurial university" (Clark 1998, Smith 1999, Clark 2004, Etzkowitz 2004, Gibb 2012, Etzkowitz 2013, Sam and van der Sijde 2014). Universities are increasingly defined by entrepreneurial activities (Heinonen and Poikkijoki 2006, Shattock 2009), and the field of entrepreneurship education is emerging at faculty worldwide teaching students to create innovative solutions based on their knowledge. Scharmer and Käufer describe the progression in a three type model of teaching, research, and practice. The suggested research approach of the future university is action research, combined with a practice-based effort to establish new collaborations between teachers, students, and external partners in order to create entrepreneurial programs, research consortiums, community action, and strategic partnerships (Scharmer and Käufer 2000) (Table 1).

\section{Innovation and entrepreneurship in the humanities}

The humanities represent great diversity in terms of scholarly disciplines, research, and education, which are generally relevant to the cultural education of citizens and the 
Table 1 Historical university developments

\begin{tabular}{|c|c|c|c|}
\hline Concept of university & Teaching & Research & Practice \\
\hline $\begin{array}{l}\text { Scholastic, middle age } \\
\text { university; } \\
\text { 'unity of teaching' }\end{array}$ & $\begin{array}{l}\text { Teacher presentations } \\
\text { Students as co-listeners, } \\
\text { co-thinkers }\end{array}$ & & \\
\hline $\begin{array}{l}\text { Humboldtian, classic } \\
\text { university: } \\
\text { 'unity of research and } \\
\text { teaching' }\end{array}$ & $\begin{array}{l}\text { Teacher presentations, } \\
\text { seminar style studies, } \\
\text { students as co-speakers }\end{array}$ & $\begin{array}{l}\text { individual researchers " } \\
\text { in solitude and freedom" } \\
\text { institutes }\end{array}$ & \\
\hline $\begin{array}{l}\text { 21st century university: } \\
\text { 'unity of praxis, research, } \\
\text { and teaching' }\end{array}$ & $\begin{array}{l}\text { Entrepreneurial studies, } \\
\text { students as co-initiators, } \\
\text { co-actors }\end{array}$ & $\begin{array}{l}\text { Action research, research } \\
\text { consortium community action } \\
\text { research }\end{array}$ & $\begin{array}{l}\text { Strategic partnerships; } \\
\text { partnerships with startups, } \\
\text { ventures, and venture } \\
\text { capitals }\end{array}$ \\
\hline
\end{tabular}

Adapted from Scharmer and Käufer 2000

development of democratic and open societies (Holm et al. 2015). Recent studies suggest that humanistic competencies such as reflection, criticality, and knowledge creation can be harnessed into creative, innovative, and entrepreneurial competencies with societal, cultural, and economic impact (Jensen 2012, Etzkowitz 2014a, 2014b, Gulbrandsen and Aanstad 2015). Studies in entrepreneurship education (Erikson 2003, Matlay 2006, Blenker et al. 2014) and our local educational practices at the humanities (Jensen 2012, Jensen 2014) indicate that entrepreneurial competencies can be supported through engaging with external partners for the benefit of students in their learning processes, career choices, and for the benefit of society and industry, as well. The Triple Helix provides a conceptual approach to integrate external partners into innovation and entrepreneurship education for developing and supporting students' entrepreneurial competencies, which can be explored and evaluated through Educational Action Research.

\section{The theoretical foundation of EARTH}

In the following sections, the fields of Educational Action Research and Triple Helix are presented and compared in order to illustrate the uniting elements of the EARTH design. We have sought to identify key principles in both fields.

\section{Educational Action Research}

At the launch of the Action Research Journal, Brydon-Miller et al. refer to Reason and Bradbury's definition of action research:

"A participatory, democratic process concerned with developing practical knowing in the pursuit of worthwhile human purposes, grounded in a participatory worldview which we believe is emerging at this historical moment. It seeks to bring together action and reflection, theory and practice, in participation with others, in the pursuit of practical solutions to issues of pressing concern to people, and more generally the flourishing of individual persons and their communities" (Brydon-Miller et al. 2003)

The definition integrates many of the principles in the fields of action research and Educational Action Research. The legacy from Lewin emphasizing a democratic process is included as well as the participatory, collaborative, and co-creating elements that are 
pointed out as important dimensions of an action research approach (Genat 2009, Bradbury-Huang 2010, Taylor et al. 2012). A significant aspect of action research is the outcome focus on action and practical solutions that distinguishes the field from other research approaches (Cronholm and Goldkuhl 2004, Sexton and Lu 2009). In addition to the focus on practical issues is an awareness of the nature of these practical solutions; they are developed in and for a community of interest, to empower people and societies, and basically to create a better world and social change through voluntary and emergent processes (Brydon-Miller et al. 2003, Bradbury and Reason 2008, Kemmis 2009, Kinsler 2010, McNiff 2013, Kemmis et al. 2014, Townsend and Thomson 2015).

Educational Action Research examines both the potentials, as well as the challenges, of an educational and research practice centered on collaborative projects with various internal and external partners (Peters 2004, Ramstad 2008, Kemmis 2009). Combining the roles of teacher and researcher through action research enables academics to initiate changes such as democratic empowerment, social change, and professional development (Collins et al. 2006, Kemmis 2009, Sexton and Lu 2009, Somekh and Zeichner 2009, Walton 2011, Greenwood 2012, Townsend and Thomson 2015). Reflection is a strong element in the literature both in action research and Educational Action Research. Some link reflection to action, while others describe and discuss reflection on processes, interactions, and one's own role (Burchell and Dyson 2000, Clegg 2000, Leitch and Day 2000, Staniforth and Harland 2003, Phillips and Hollingsworth 2005) as well as the taken-for-granted assumptions of researchers (Smith et al. 2006 , Townsend and Thomson 2015). Especially, the literature on Educational Action Research has a tendency to focus on reflections on practice, learning, and professional development (Burchell and Dyson 2000, Clegg 2000, Goodnough 2003, Staniforth and Harland 2003, Peters 2004, Taylor and Pettit 2007, Elliott 2015).

Consequently, the teacher as action researcher plays a central role in initiating projects based on the above principles; there is a strong request for internal and external collaboration with emphasis on emerging communities through an integration of the interests of the involved partners kept in a voluntary, empowering, and equal atmosphere; the community and the project should develop practical solutions and create societal change; and there is a demand for reflection and professional development, while documenting this through research activities. In an educational reform context, Educational Action Research has the potential to make a unique contribution by eroding the boundaries between action and knowledge-generation and bringing educational transformation that other traditional research approaches may not succeed in due to conventional constraints (Somekh and Zeichner 2009).

\section{Triple Helix Theory}

Innovation in the dynamics of Triple Helix collaboration involves participation from partners of at least three different sectors: academia, government, and industry (Etzkowitz and Leydesdorff 2000). This collaboration is dependent on voluntary associations in an active civil society and the possibility of individuals and groups to freely organize initiatives in a Triple Helix formalization that may include both bottom-up and top-down initiatives (Etzkowitz and Dzisah 2013, Etzkowitz 2014a, 2014b). Innovation can occur in the process of collaboration between actors from different sectors who are traditionally perceived as 
functioning according to their own resources, rule-based approaches, methodologies, and interests. Social actors may acknowledge actors from other sectors when overall goals are mutual and the condition for success is dependent upon each-other's actions and competencies. With the ideal assumption of mutual dependency, the Triple Helix model presumes equality in relations between partners (Etzkowitz and Leydesdorff 2000). In the words of Marina Ranga and Henry Etzkowitz;

"This is where creative synergies emerge and set in motion a process of 'innovation in innovation, create new venues for interaction and new organizational formats, as individual and organisational actors not only perform their role, but also 'take the role of the other' when the other is weak or under-performing" (Ranga and Etzkowitz 2013:239)

The notion of 'taking the role of the other' is a concept of systemic mutuality that depends on a general transition towards more integrated relations between the three sectors in society, which represents the change from industrial society to the knowledge society. Knowledge is a valuable driving mechanism for innovation and growth (Etzkowitz and Klofsten 2005, Lee and Ngo 2011), wherefore academic intellectual resources and human capital become promoted foundations for innovation and collaboration. In this context of societal transition, the Triple Helix theory states that academia can take a leading role as innovation organizer (Etzkowitz and Leydesdorff 2000, Ranga and Etzkowitz 2013). An 'Innovation Organizer' often takes the responsibility to initiate and organize a mutual innovation project that serves the interests of the involved partners (Ranga and Etzkowitz 2013). In the Triple Helix system framework, the Innovation Organizer may therefore select or mediate between specific actors, i.e., individuals, from available sectoral components, thereby defining the relationships between actors and the competencies needed in order to realize functions of the Triple Helix, which are mainly to generate, diffuse, and utilize knowledge and innovation (Ranga and Etzkowitz 2013). Variations in innovative performance of Triple Helix systems are explained by the development of actor relations in interactional spaces of knowledge flows, innovation, and consensus. The variety of articulations between these spaces and related performance outcomes depends on the actual organizational practices of Triple Helix actors, which may then foreground the importance of an innovation organizer at the level of individuals.

\section{Theoretical foundations of EARTH: principles of educational action research and Triple Helix}

Below, some of the more important and shared principles of the two fields are illustrated in the attempt to draw attention to the possibility of combining theories for developing the EARTH design (Table 2).

In theory, what may bridge the fields of Triple Helix and Educational Action Research is the common emphasis on action as knowledge generation, and engagement in collaborative, equal and voluntary constellations between actors from different contexts in the attempt to develop new ideas, solutions, or societies. The two metaphors for the collaborative projects are a community of interest and Triple Helix. In both fields, academia has a tendency to function as the initiating and organizing partner of new 


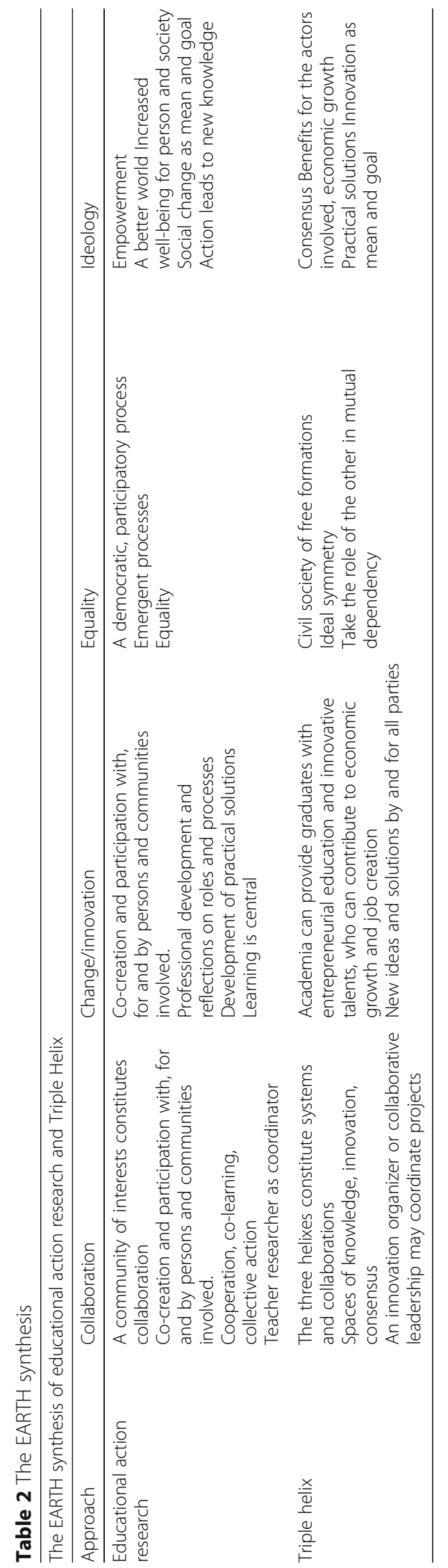


projects. The Triple Helix approach does not necessarily operate with an in-built focus on empowerment and ideologies of 'a better world' in comparison to the Educational Action Research field, but the two approaches share several principles, which we argue thereby support the development of the EARTH design.

\section{Research combining action research, Triple Helix, and entrepreneurship education}

The notion of combining Educational Action Research and Triple Helix theory in entrepreneurship education is yet an emergent research interest. Only a few studies explicitly combine entrepreneurship education and action research in higher education (Blenker 2006, Collins et al. 2006 , Smith et al. 2006 , Taylor and Pettit 2007). However, the work of the PILE-group ${ }^{1}$ presents such recommendations in a working paper based on a literature review of international research and case studies of educational practices at four European universities (Blenker 2006), which is elaborated in related articles (Blenker et al. 2007, Blenker et al. 2014). In this study, the authors theorize "a cohesive frame of reference for entrepreneurship teaching" (Blenker 2006:142) combining the Triple Helix model with pedagogical and didactic suggestions for innovation and entrepreneurship education in order to build university-based practice communities by constructing networks of students, teachers/researchers, and business people. At the center of the development towards Triple Helix model integration, the PILE-group positions the teacher as an agent for cultural change in relation to teaching curriculum, research projects, and of managing professional network relations. By taking the double-role of teacher-researcher and adopting an "academic-practice angle" (Blenker 2006:120) inspired by action research, teachers can develop their significant role in bridging the three sectors. The authors suggest that the collaboration between sectoral actors may be most realistically performed if networks are first constructed among students in the form of project work in groups of students with backgrounds in different academic fields. The teacher-researcher is therefore uniquely positioned to create course designs that support practice changes for meeting new learning requirements from students, university administration, government, the business sector, and from society in general. This approach integrates triple-helix relations and provides new theoretical solutions to support a paradigmatic progression towards the entrepreneurial university. The PILE group work has inspired us to elaborate on the theoretical synthesis of educational action research and Triple Helix theory and to apply these insights into the practical design of a university course in innovation and entrepreneurship with specific attention to the interaction between the different actors.

\section{Approach and development of the EARTH design}

\section{The local context of innovation and entrepreneurship education}

In the autumn of 2013, we organized a three-person team of teachers and teacherresearchers with the task to teach five parallel classes of a shared course in the spring of 2014. The title of the course is "Innovation, Project management and Teamwork" ("IPT" hereafter) and is part of the educational program International Business Communication in The Humanities at the University of Southern Denmark. Undergraduate students at the fourth or sixth semester enroll in this course, which is elective for students from other educational programs as well. In the course, the students combine different forms of formal training from their academic background and experience-based competencies from 
their daily lives into a team-based collaborative and innovative project with other students and various external partners. The students have to obtain theoretical knowledge about the fields of innovation and entrepreneurship, project management, and teamwork; acquire analytical and practical skills to be able to develop and implement innovative ideas in collaboration with others; and develop innovative and entrepreneurial competencies. The students pass the course by active participating in the activities of the 13 weeks (see Table 3), which includes oral presentations of the team's idea, reviewing other teams' ideas, interacting with external actors, and writing a business plan. During the course, the teachers/researchers monitor the students' progress in teams and overall learning goals (as stated above) through a combination of lectures, team workshops, and task deadlines. At the beginning of the course, the teacher-researchers introduced and explained the EARTH design to the students regarding both Triple Helix theory and educational action research, and how these are practiced in the course. Reflecting upon prior experiences of ad hoc involvement of external actors, we decided to combine Triple Helix theory and educational action research to build a more systematic methodology for integrating known and new external relations in alignment with curriculum and learning goals (Fig. 1).

The EARTH methodology is inspired from the "Learning Cycle" by Kolb (Kolb 1984, Vince 1998), which describes a cycle of experiential learning in four phases of (1) concrete experience, (2) reflective observation, (3) abstract conceptualization, and (4) active experimentation. This motion captures the original beginning of the EARTH design as concrete experiences of teaching innovation and entrepreneurship courses constitute the groundwork for joint reflective observations and consequently abstract conceptualizations of combining educational action research and Triple Helix theory into a course framework. The new framework involves active experimentation of Triple Helix actor relations with the overall research aim to explore how such interactions may support student learning and innovation activities. Empirical experience provides ground for further observational reflections, conceptualizations, and active experiments in a potentially continuous cycle of experiential learning within the EARTH methodology until the process is discontinued. Central to this method is the selection of sectoral actors (step 3) that are expected to contribute to students' learning processes, competencies, idea development, and opportunities of innovative collaborations. The selection of sectoral actors is illustrated with an adaptation of the original Triple Helix conceptualization (Etzkowitz and Leydesdorff 2000), (Fig. 2).

The Triple Helix figure reflects a multi-layered constellation of actors with different roles contributing with knowledge-specific tasks and categorized in terms of sector affiliation. Part of the course design includes employment of a serial entrepreneur functioning as a co-teacher in more than half of the time in the IPT classes. Therefore, the entrepreneur figures as a hybrid academic actor in the model. This programmatic pre-selection of the different sectoral actors participating in the course reflects the idea of the teacher-researchers as innovation organizers.

The four main program dimensions of the EARTH-design are illustrated in Table 3. The distributed integration of Triple Helix actors (3) is demonstrated in direct connection with aspects of the course curriculum (1) and learning goals (2), which are interrelated dimensions that are examined through action research and a combination of methods (4). 


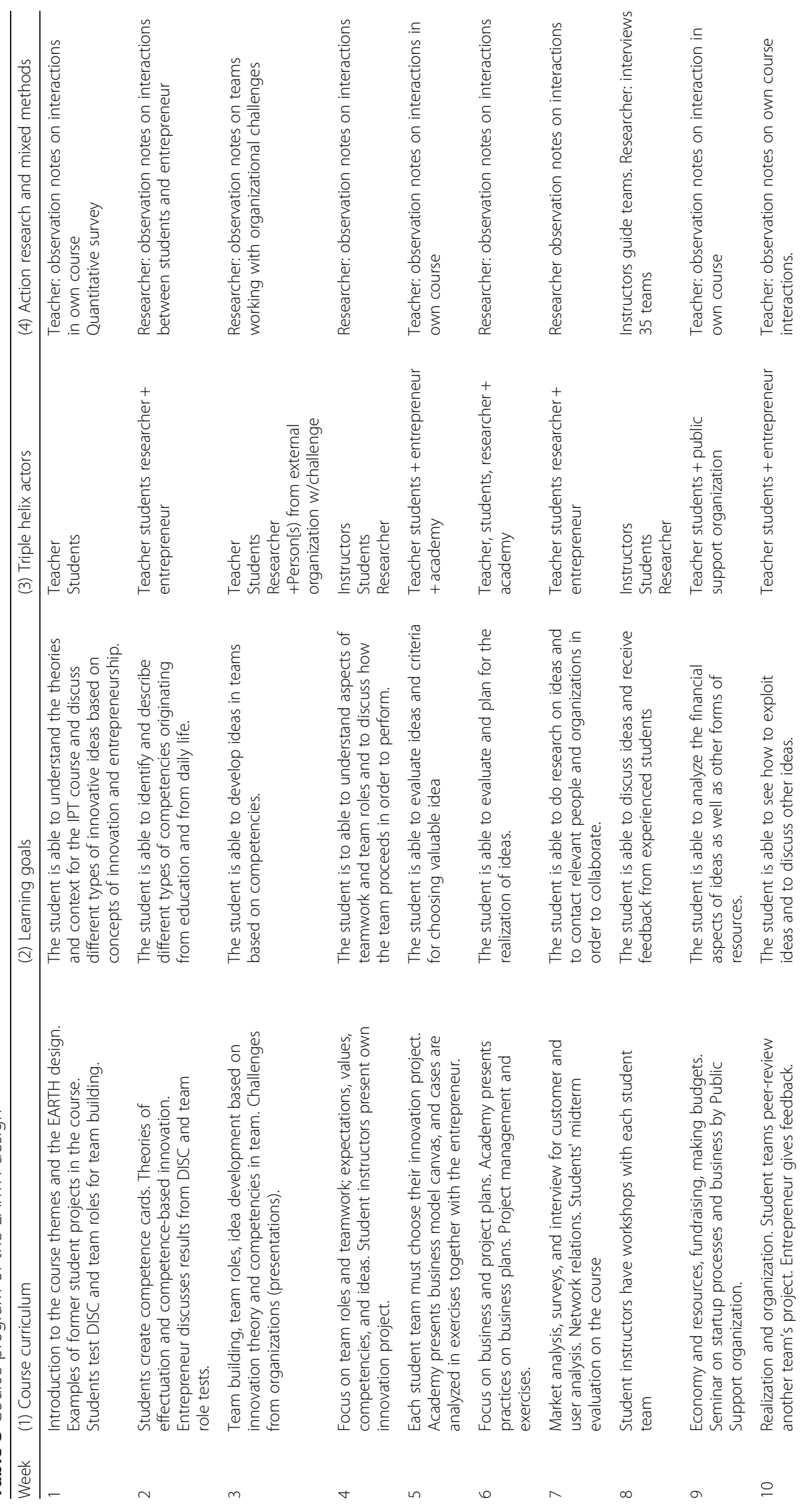




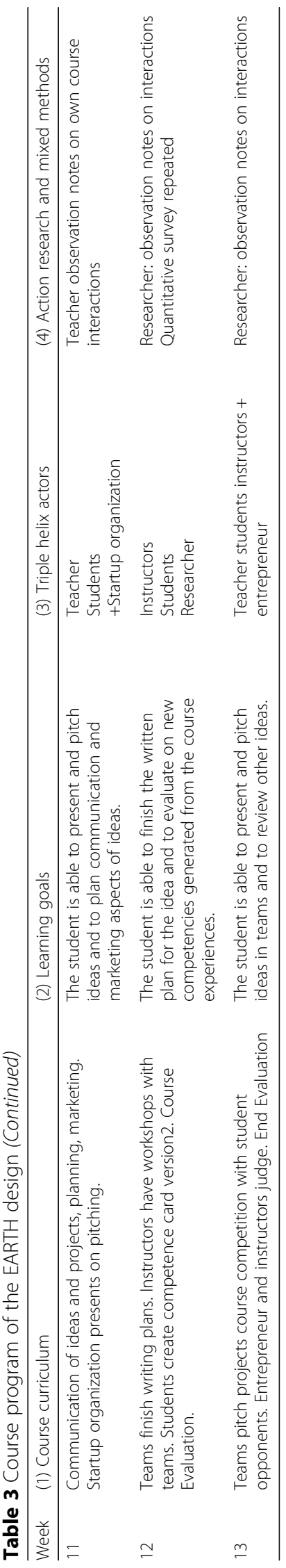




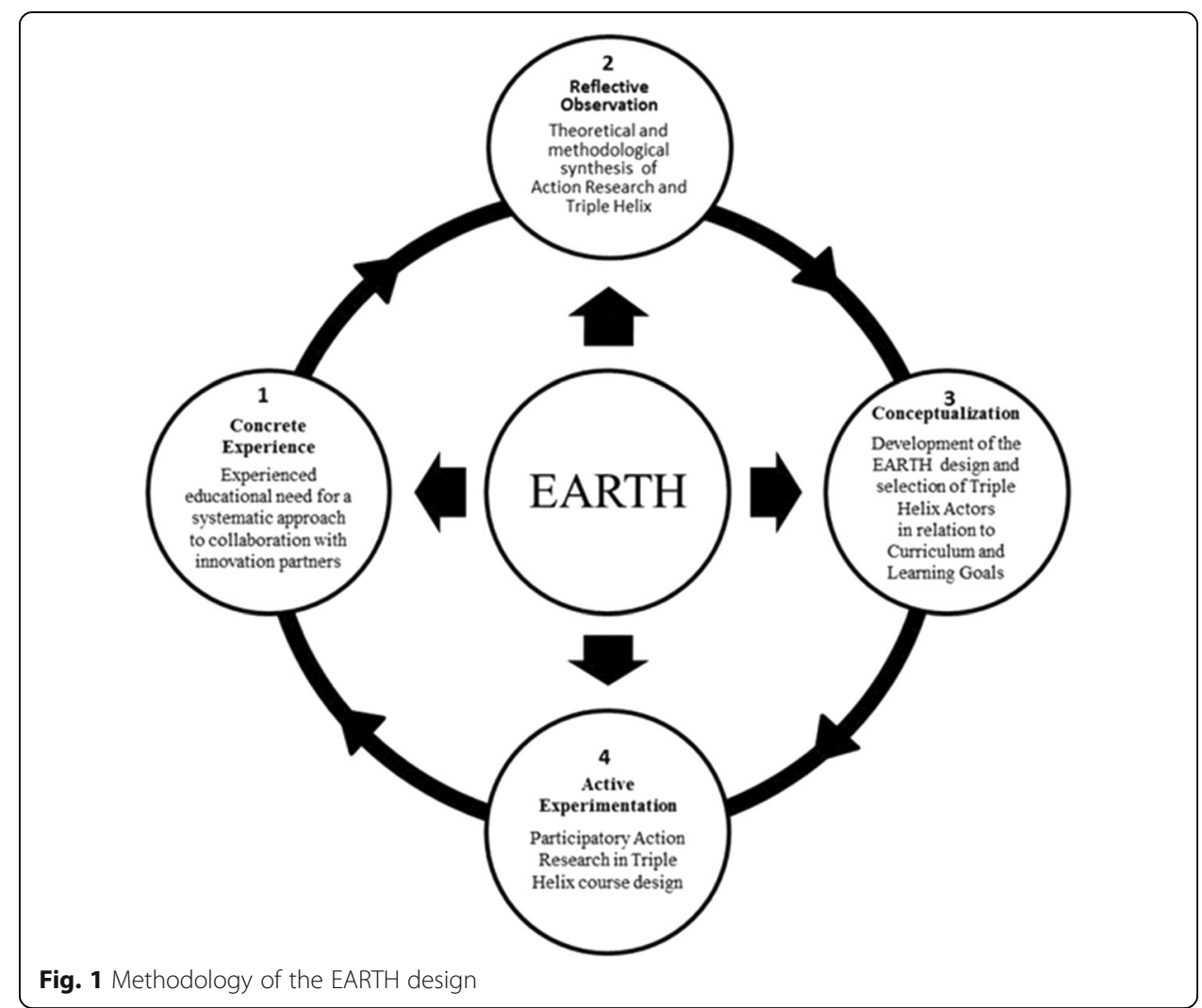

\section{Research methodology}

At the beginning of the courses, the two teacher-researchers introduced the research project to the students and obtained their oral informed consent. All students were offered the right to opt out of the research project at any given time of their choosing. However, there was not a single incident of this during or after the research project. We explored the EARTH-design with a mixed method

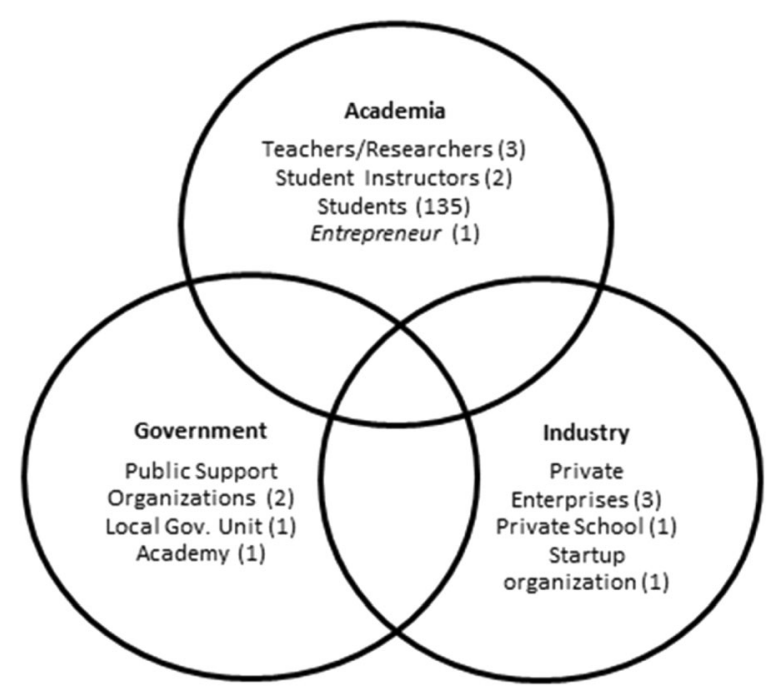

Fig. 2 Triple helix Implementation in the Educational Context 
methodology. Mixed methods examine processes both in depth through qualitative data and widely by quantitative data (Creswell 2009, Bryman 2012) allowing collection of different types of evidence in different situations throughout a research process. An exploratory sequential study, where one type of data informs the next, was chosen. This approach is often used in educational research (Creswell 2009). In five classes of the course, we performed qualitative participatory observations on our own and each other's teaching. Simultaneously, we observed students' interactions with each other and the external actors. Midway through the course, we conducted qualitative semi-structured interviews with the student teams $(N=34)$ about their experiences with internal and external actors to be able to reflect in collaboration with the students upon the general process as prescribed in the action research approach: e.g., (Q.6) "What have you gained from having different external presenters available in the course?"; (Q.7) "Have you benefitted from direct consultation with the external actors in the course, and if so, did you experience that this had influence on your project?"; and (Q. 8) "On basis of your knowledge of the different external actors in the course - do you now have less or more motivation towards engaging similar people in connection with future projects during your education?." A quantitative survey with individual students $(N=119)$ was done at the end of the course with the purpose to measure their attitudes, competencies, and project-based relations and to evaluate their academic and entrepreneurial developments. Furthermore, all students $(N=134)$ were required to create an individual competence card of their educational and experience-based competencies at course start in order for the teachers to mix them in complementary teams of 3-4 persons. After the course, the students updated the competence cards to describe their competencies and learning development, which are part of the empirical data.

\section{Results}

The research project has generated a substantial amount of empirical data. In the following, we will focus on data pointing to knowledge about the interaction between the various actors involved in the process with emphasis on the students' experiences at individual and team-based levels. For conceptual clarity, the analysis follows a threestage exploration according to distinctive functions of the actors involved, after which the dynamics of the EARTH design are summarized:

1) In the first stage, we explore data on the primary relations between internal and external actors who actively participated in the course with teaching hours, presentations, or workshops. These actors include 135 students, 3 teachers (2 researchers), 2 student instructors, a serial entrepreneur, and 4 public or private organizations supporting entrepreneurship.

2) In the second stage of analysis, we describe the course relations of the five organizations invited to present innovation challenges for engaging in collaboration with student teams. These actors are termed secondary design relations.

3) In the third stage of analysis, we present descriptive data on the tertiary relations initiated by many of the student teams generating project-based networks beyond the formal provisions of the course design. 


\section{Primary relations}

The combination of primary actors created a dynamic classroom. Interviewed about the experience of having different actors in the course (Q.6), the majority of teams responded positively (28 of 34 teams) and several students responded with similar expressions; "It was mega cool, I think it has been extremely cool" (team 8); and "I remember when she [student instructor] came and told her story, I think that was just extremely inspirational, and then you [the teacher-researcher] come and tell your story, and then (the entrepreneur) also comes and tell his story, oh, I think that was mega cool" (team 8). One student declared "I think it has been really good, also for creating variation in teaching" (team 5); another said "I think it was really good. I think they are very competent and it gives a good dynamic" (team 31); and a third student concluded "It has made it [the course] more lively and created something real" (team 24).

These experiences are substantiated by a majority of findings between interviews, which confirm that students recognize the significance of multiple actors and the need for different information sources, as noted: "It has been nice in that we have heard different stories, and something like that, you know, and some different aspects of how it is to start up something new by yourself" (team 16); and "you [the teacher] do not have a lot of students, who actually do not really know what they should do, and we have a lot of questions, and I think it is nice that we can get input from different [people]" (team 5).

These and other statements imply that students have questions that a teacher may not be capable of addressing alone, which necessitates other perspectives, competencies, and involvement of individuals from academia, industry, and government:

"That day when we were in our groups, we talked with both you [the teacher] and [the teacher-researcher] and [the Academy], and it was like, we just got input from all you three, which we could actually use, I think, seen from three different perspectives. I think it is extremely good, that is, it is some of the best that I have actually experienced until now in a course teaching." (team 5)

Generally, the participation of different primary actors in the course was a very positive experience. Actors were perceived according to their specific roles and performance of competencies in the course, which account for variations of interactions and impacts upon learning.

Most notably, students gained vicarious learning through actors' experiences, different perspectives, inspiration, and experiences of turning theory into practice, which supported realism and students own real-world experiences of innovation and entrepreneurship.

These qualitative insights via team-based interviews present us with some main dynamics of the EARTH design, which we quantified with content analysis (Bryman 2012) in order to assess some of the effects broadly (see Fig. 3).

The results in Table 4 reflect the overall learning goals of the course design (page 7), which formally require that "The students have to obtain theoretical knowledge about the fields of innovation and entrepreneurship, project management and teamwork; acquire analytical and practical skills to be able to develop and implement innovative ideas in collaboration with others; and develop innovative and entrepreneurial competencies." In this summary of interview data, the students responded that they gained 


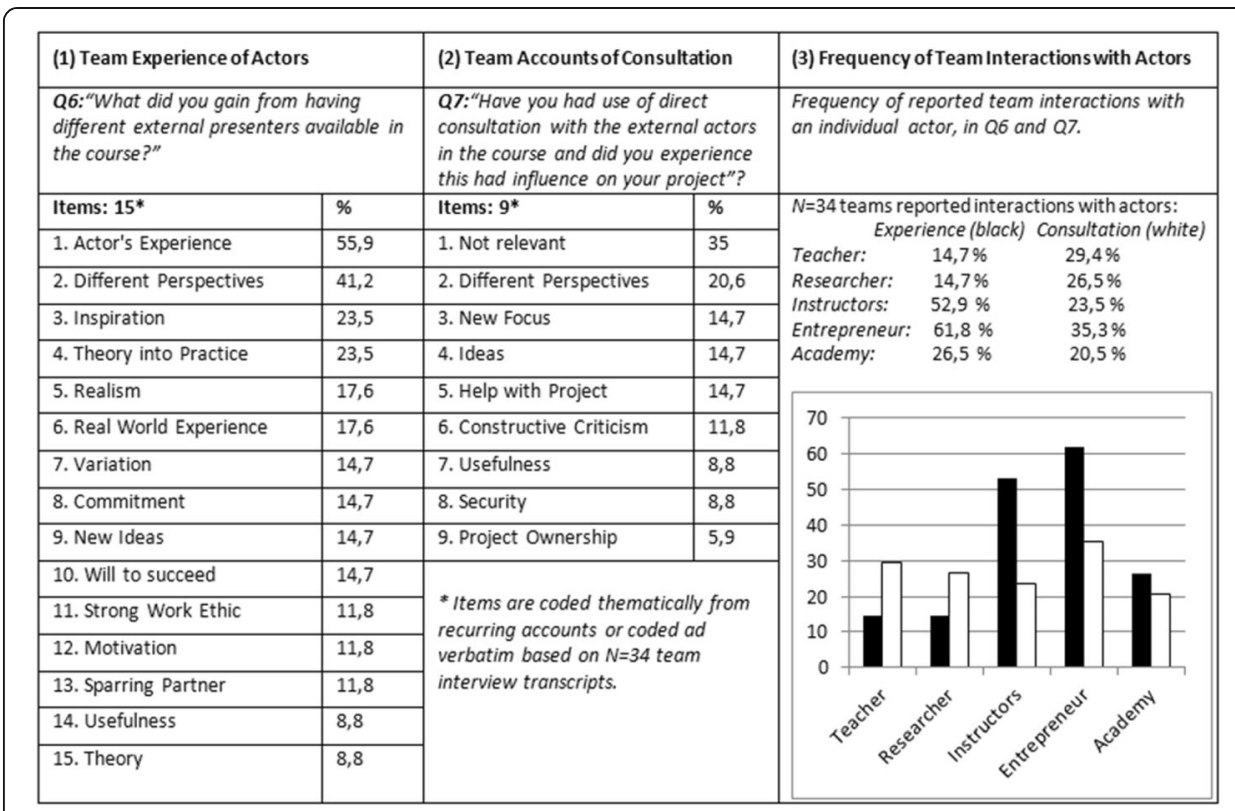

Fig. 3 Student teams' experience of primary actors

what can be characterized as elements of learning relevant to the overall goals by interaction with the external actors. Grouping these responses around the learning goals, we can state that the students did obtain theoretical knowledge (theory), analytical and practical skills (theory into practice, realism, real-world experience, commitment, will to succeed, strong work ethic, motivation), and abilities to develop and implement innovative ideas (inspiration, new ideas, variation) in collaboration with others (sparring partner, actor's experience, usefulness).

The remarkable response that consultation with the actors was not relevant (35\%) reflected that numerous teams were either self-reliant by applying skills and knowledge within the team to "run the show ourselves" (team 16) or that they were relying on other relations besides the primary actors. While this show of self-reliance and team autonomy may be interpreted as positive entrepreneurial behavior, it also prompts the question whether a stronger emphasis on co-creation through which students are involved in designing projects and selecting external organizations from the outset might have resulted in a higher report of external actor relevance in terms of consultation and the students' investment in these possible relations. Also, this consideration of more co-creation in the construction of the EARTH design to include students' informed preferences about external actors would be in better accordance with action research principles. However, and in contrast to these cases of non-interaction, the majority of teams (65\%) sought and experienced direct consultation from which they acquired positive contributions.

Some teams made a clear distinction between the actors' competencies based on academic or personal background and a certain perception of reality that invokes sectoral divisions in the EARTH design between academia and industry. Different authorities and competencies are ascribed to the actors, wherefore contributions seem to be categorized according to students' distinctions between the university context and the 'real world'. 
The entrepreneur was regularly referenced for his real world experience of starting up and managing businesses:

"... and we have actually received some feedback from an entrepreneur, who can actually see the light in what we have [created] and tells us, well this is good, and speaks his mind about it, well this, this is a bad idea ... pushing on strengths and weaknesses so that we can find ourselves and that this in some way activates us ... so that we actually think we can succeed and that we actually have more passion about it than merely thinking it is just a course that we need to pass." (team 6)

However, the statement below suggests that a sense of security is reached by the team's orientation for information from both dimensions of theory and practical experience:

"We have had very much use of...both you [the teacher] and [the entrepreneur] ... well [the teacher-researcher] has the same background as us, and then there is [the entrepreneur] from the real world and you [the teacher] bring something theoretical ... but you can all see the idea in what we have set out to do ... and that has given us great security" (team 1)

Processes of valuation are inherent in students' assessment of actors. By conducting a questionnaire we intended to capture each student's perceived 'usefulness' of primary actors on a 5-point Likert scale (Fig. 4):

The entrepreneur and the student instructors contributed significantly to the student teams' competencies and project ideas and were therefore valued as the most useful actors in this context. These general results are in accordance with the qualitative data findings of team interactions with primary actors (Fig. 3). Findings support the theoretical EARTHdesign assumption that diversity of actors in the course provides complementary functions, where dynamics of substitution allow actors to "take the role of the other' when the other is weak or under-performing" (Ranga and Etzkowitz 2013). This is specifically evidenced as the entrepreneur provided practical expertise from real-world experiences of startup and business management thus substituting the teachers' theoretical role and functions. The substitution of different actors' involvement in the EARTH-design clearly enhanced students' learning outcomes. Furthermore, the educational context supported mutual interests between diverse actors about promoting innovation and entrepreneurship to university students in the form of knowledge collaborations.

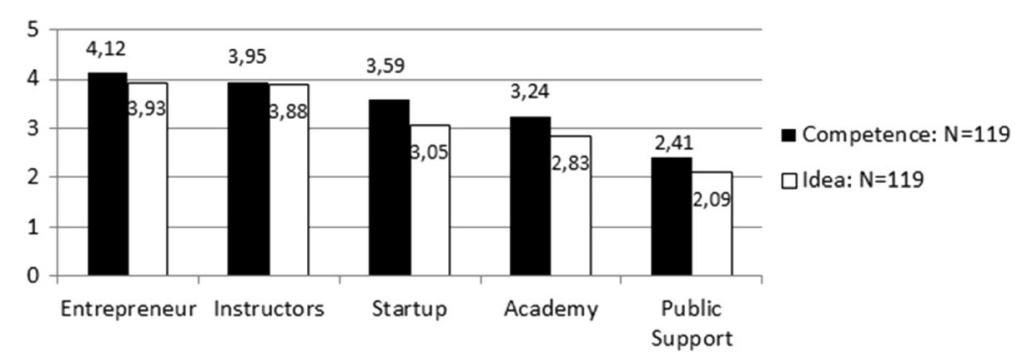

Fig. 4 Students' rated influence of each actor in relation to competence and idea 


\section{Secondary relations}

Based on the EARTH design, five organizations from diverse sectors were involved in the course pre-setting of possible innovation collaborations between student teams and organizations. Three organizations were selected by student teams for active innovation collaboration. Reasons for both engaging and not engaging with external organizations were questioned by measuring the students' responses to their perceived relevance of the innovation challenge(s). Approximately one half (47\%) responded positively and another half (48\%) responded negatively or indifferently to the relevancy of organizational innovation challenges. The responses were qualified with observations and dialogues with some students who expressed that they wanted to develop ideas themselves rather than participate in an already defined collaboration with an organization. This would indicate that the course provides ground for supporting self-reliance and creativity that allows for venturing beyond traditional academic frameworks rather than satisfice with constructed opportunities. However, for those students who engaged in secondary relations, these organizations were registered in competencies cards as part of the students future networks thereby indicating a measure of collaborative success.

\section{Tertiary relations}

The student teams were encouraged to establish their own contacts and collaborations with external partners to realize their projects and business ideas or to develop new solutions together with existing organizations in the private sector, in the government sector, and in the community sector. This encouragement created conditions for frequent and intensive student activity beyond the classroom and in-between days of course teaching. At course end, students were asked if they or a member of their team initiated contacts with any organization. A majority of the students (79\%) reported that they or someone in their team initiated contact with external organizations beyond the course presetting of primary and secondary relations, which accounts for network activities for 28 teams of 34 . Of these 28 teams, 9 teams engaged directly in Triple Helix collaborations with actors from three different sectors thereby taking on the role of Innovation Organizer themselves. The highest frequency of contact was made in the private sector, and many contacts were initiated in academia closer to the students' habitual surroundings and networks. New relations were established in the civil sector and government sector, as well. Of all the 34 student teams, 8 teams realized their innovation projects, and only 7 teams remained on a purely conceptual stage in their idea generation and did not commence network relations with tertiary actors. Data from the student competence cards at the end of the course show that approx. $70 \%$ of the students included tertiary actors as part of their present network. Interview data clarified some common motivations for student-initiated networking and Triple Helix collaborations, which ranged from recruiting additional skills to the team to seeking expert knowledge in different subjects and seeking working partners for sharing resources and realizing projects.

\section{Dynamics of the EARTH design}

The EARTH design provides an integrated system of primary and secondary actors in accordance with the specific curriculum and learning goals of a university course. Primary network relations are thereby established based on the educational program 
between academia, industry, and government in various interactions between the teacher, the teacher-researchers, the entrepreneur, student instructors, and actors from the public and private sectors. Moreover, the EARTH design introduces innovation challenges from external organizations as secondary relations and students initiate tertiary relations of innovation collaboration. To conceptualize these productive effects at the level of individuals in the EARTH design, a number of interpretative aspects are suggested by the data covering at least five considerations that are significant for understanding a range of social dynamics: (1) competence performance; (2) identification; (3) structural legitimization; (4) designed actor relations; and (5) perceived usefulness.

First and foremost, student teams evaluate the actors according to their (1) competence performance. The students make a clear distinction between actors' competencies based on educational, vocational, or personal proficiencies and a certain perception of reality that invokes sectoral divisions in the EARTH design between academia and industry. Furthermore, the teachers and student instructors are recognized as having the same academic background as the students, which strongly suggests (2) identification in terms of social grouping. Expressions of identification also suggest that the student instructors may have attained key positions as role models, whereas the entrepreneur was professionally positioned as the most competent in terms of entrepreneurial experience. Furthermore, competence performance and identification are contingent upon a third aspect, (3) structural legitimization, which may be conceptualized as the contextual agreements of how actors are involved in the course. Actors such as the entrepreneur and student instructors are authoritatively better positioned by being internal institutional actors along with the teacher and teacher-researcher in comparison with the academy and by categorical association The startup organization and the public support organization, as well. The dichotomy of institutional embeddedness versus peripheral participation is to a large extent an arbitrary construction of legitimacy that derives from (4) designed actor relations subject to a regulatory process of how actors are actively related in the course. In principle, the position of each actor is therefore interchangeable in terms of formal affiliation and choice of design, whereby actors could in theory be replaced, pulled or new ones added to the course. Lastly, these four aspects are fundamentally influenced by a fifth aspect, (5) perceived usefulness, which is the very selection of actors in the design based on theoretical and practical considerations by the teacher-researchers (i.e., the authors). The selection of actors is therefore in part tested by the students' assessment of actors' usefulness (Figs. 3 and 4) summarizing main effects of the designed interactions at the level of individuals. The EARTH design may therefore be improved based on the students' experiences of the primary, secondary, and tertiary actors in relation to learning goals and opportunities of innovation collaboration.

\section{Discussion and conclusion}

Discussion

According to the Triple Helix theory, asymmetric constellations are in terms of different actor's competencies a significant premise and mechanism that creates new innovative processes, ideas, and products (Ranga and Etzkowitz 2013). However, 
compared to the shared ideal of mutual interest in both Triple Helix theory and action research, such asymmetries may produce paradoxes between principles of equality, consensus, and issues of leadership. Actors from different sectors may not be equally involved or resourceful. Therefore, an Innovation Organizer necessarily takes lead thus constructing a hierarchy not entirely compatible with action research ideals. Creating a completely mutual collaboration project for all actors to initiate and take part in simultaneously did not succeed in this particular context, which may be an ideal more than reality in most projects. Rather, the present design functioned as an organizational practice with the teacher-researchers as innovation organizers, which involved the complementary contributions of diverse actors having incursions into the course with varying duration, frequency, and interests. The study indicates that students and other individuals in a collaborative Triple Helix project are in need of different degrees of Innovation Organizing at different times during the processes depending on the requirement for independence and interaction. Therefore, the teacher-researcher role calls for the ability to initially act as pre-organizer to set the collaborative framework, which is followed by the will to let individuals self-organize in the various processes. Finally, the teacher-researcher may take on the role of Innovation Organizer again at the end of the course to ensure that the students' innovation projects and the Triple Helix framework are both progressing in accordance with learning goals and practical solutions. The challenge is the willingness and competence to balance between shared and systemic demands and needs in an innovation course setting versus the individual students' freedom to navigate in their own projects with all the possibilities and collaboration 'loops' this may imply.

\section{Conclusion}

In this article, we presented the theoretical and methodological development of a new course design for exploring Triple Helix collaboration in innovation and entrepreneurship education. Action research seems to offer an effective approach for bridging sectoral partner interests around diverse types of innovative projects into forms of Triple Helix collaboration that may expand beyond the classroom context, which confirms previous research suggestions (Blenker 2006). The EARTH-design builds a foundation for exploring innovation and entrepreneurship education that focuses on innovation collaboration and student's learning via Triple Helix principles (D'Este and Perkmann 2011, Etzkowitz 2014a, 2014b). The involvement of different primary and secondary actors in the course create productive conditions for students to acquire entrepreneurial experiences directly or vicariously through social relations and mastery of converting theory into practice (Erikson 2003), which supports the role of student innovation that may have direct encouraging effects upon students' motivation for initiating innovation collaboration with tertiary actors beyond the pre-settings of the course. This is in accordance with previous calls for entrepreneurial universities that should be "offering a curriculum that is current in knowledge terms; that seeks to assist in students' engagement with external settings; and that may expand its students' confidence to live in a changing, complex world" (Shattock 2009:51). Comparable to prior research on entrepreneurship education (Collins et al. 2006 , Kirkwood et al. 2014), the EARTH design 
results in a general student experience of 'real world' innovation and entrepreneurship, which is supported by substitution of actors where one actor is able to 'take the role of the other', and vice versa. In the educational design of integrating Action Research with Triple Helix theory and recruiting primary and secondary actors, teacher-researchers are as representatives of Academia in similar manner to the following description by Ranga and Etzkowitz "providing support and even funding to encourage entrepreneurial ventures, thus enacting some of the traditional role of industry" (Ranga and Etzkowitz 2013:246). Reciprocally, these external actors' participation in teaching and in providing innovation challenges to student teams, partly enact the assertion that "Industry can also take the role of the university in developing proprietary education and training solutions" (ibid).

In conclusion of this study, and with reference to the research questions outlined; we have presented how university education can integrate Triple Helix collaboration in support of students' learning and contribution to innovation by designing a course framework for selecting key actors in accordance with curriculum and learning goals (Table 3). In the EARTH design, key actors can be substituted, added, and excluded in further selections based on student evaluations, which may continue learning cycles within the EARTH methodology. The theoretical synthesis of Educational Action Research and Triple Helix provide both means to construct and to research these relations within an educational setting.

Considerations for future improvements are to bring the ideal principles into practice by organizing mutual collaborations before, during, and after the course. This will require that innovation organizers, i.e., teacher-researchers, are willing to distribute leadership and relinquish control of their 'specialist' functions thereby allowing more or equal participation from other actors in the planning, implementation, and research processes. While this particular project remained within the perspectives of both teacher-researchers and students for construction and assessment of the design, EARTH projects should include perspectives and assessments from every sector participant. The design is an ideal based on principles from two research fields and can potentially take many forms as the variance and quality of innovation performance depends on the actor relations in interactional spaces of knowledge, innovation, and consensus. Therefore, future prospects for supporting, e.g., collaborative leadership (Ranga and Etzkowitz 2013) may require that actors involved in the EARTH design establish mutual Triple Helix spaces that involve both student-centric and collective learning in an open space of knowledge that connects to spaces of innovation and consensus in project collaborations. Such collective and mutual leadership in the organizational field of the Triple Helix may require additional formalization between actors involved in terms of funding, contracts, written procedures and transparency of decision-making that allows for both linearity and non-linearity in a stabilized "institutional order" (Benner and Sandström 2000). In this view, the EARTH design may present a methodological step towards further institutionalizing the Triple Helix at the level of individuals on the basis of action research in innovation and entrepreneurship education.

\section{Endnotes}

${ }^{1}$ The PILE group acronym: "Pedagogical Innovation of Learning in Entrepreneurship". 


\section{Additional file}

Additional file 1: Translation of the abstract into Arabic. (PDF $255 \mathrm{~kb}$ )

\section{Authors' contributions}

The authors declare that the article is based on joint collaboration and equal contributions. Both authors read and approved the final manuscript.

\section{Competing interests}

The authors declare that they have no competing interests.

\section{Publisher's Note}

Springer Nature remains neutral with regard to jurisdictional claims in published maps and institutional affiliations.

Received: 12 January 2017 Accepted: 21 November 2017

Published online: 22 December 2017

References

Benner M, Sandström U (2000) Institutionalizing the Triple Helix: research funding and norms in the academic system. Res Policy 29(2):291-301

Blenker P (2006) Entrepreneurship education — the new challenge facing universities: a framework or understanding and development of entrepreneurial university communities. Retrieved 04-28-2016, from http://pure.au.dk/portal/ files/32345606/2006\%C3\%A2\%E2\%82\%AC\%E2\%80\%9C02_ENG.pdf

Blenker P, Dreisler P, Faergemann HM, Kjeldsen J (2007) A framework for developing entrepreneurship education in a university context. Int J Entrep Small Bus 5(1):45-63

Blenker P, Elmholdt ST, Frederiksen SH, Korsgaard S, Wagner K (2014) Methods in entrepreneurship education research: a review and integrative framework. Educ Train 56(8/9):697-715

Bradbury H, Reason P (2008) The sage handbook of action research: participative inquiry and practice. Sage, London Bradbury-Huang $H$ (2010) What is good action research?: why the resurgent interest? Action Res 8(1):93-109

Brydon-Miller M, Greenwood D, Maguire P (2003) Why action research? Action Res 1(1):9-28

Bryman A (2012) Social research methods. Oxford University Press, Oxford

Burchell H, Dyson J (2000) Just a little story: the use of stories to aid reflection on teaching in higher education. Educational. Action Res 8(3):435-450

Clark BR (1998) The entrepreneurial university: demand and response. Tert Educ Manag 4(1):5-16

Clark BR (2004) Delineating the character of the entrepreneurial university. High Educ Pol 17(4):355-370

Clegg S (2000) Knowing through reflective practice in higher education. Educational. Action Res 8(3):451-469

Collins LA, Smith AJ, Hannon PD (2006) Applying a synergistic learning approach in entrepreneurship education. Manag Learn 37(3):335-354

Creswell JW (2009) Research design: qualitative, quantitative, and mixed methods approaches. Sage Publications, Thousand Oaks

Cronholm S, Goldkuhl G (2004) Conceptualising participatory action research-three different practices. Electron J Bus Res Methods 2(2):47

D'Este P, Perkmann M (2011) Why do academics engage with industry? The entrepreneurial university and individual motivations. J Technol Transfer 36(3):316-339. https://doi.org/10.1007/s10961-010-9153-z

Elliott J (2015) Educational action research as the quest for virtue in teaching. Educ Action Res 23(1):4

Erikson T (2003) Towards a taxonomy of entrepreneurial learning experiences among potential entrepreneurs. J Small Bus Enterp Dev 10(1):106-112

Etzkowitz H (2004) The evolution of the entrepreneurial university. Int J Technol Glob 1(1):64-77

Etzkowitz H (2013) Anatomy of the entrepreneurial university. Soc Sci Inf 52(3):486-511

Etzkowitz H (2014a) Making a humanities town: knowledge-infused clusters, civic entrepreneurship and civil society in local innovation systems. Triple Helix 2(1). https://doi.org/10.1186/s40604-014-0012-z

Etzkowitz H (2014b) Making a humanities town: knowledge-infused clusters, civic entrepreneurship and civil society in local innovation systems. Triple Helix J:-1

Etzkowitz H, Dzisah J (2013) Bottom-up Triple Helix: science policy in the states of the USA. J Knowl-based Innov China 5(2):80-96

Etzkowitz H, Klofsten M (2005) The innovating region: toward a theory of knowledge-based regional development. R\&D Manag 35(3):243-255

Etzkowitz H, Leydesdorff $L$ (2000) The dynamics of innovation: from national systems and "mode 2" to a Triple Helix of university-industry-government relations. Res Policy 29(2):109-123

Etzkowitz H, Webster A, Gebhardt C, Terra BRC (2000) The future of the university and the university of the future: evolution of ivory tower to entrepreneurial paradigm. Res Policy 29(2):313-330

Genat B (2009) Building emergent situated knowledges in participatory action research. Action Res 7(1):101-115

Gibb A (2012) Exploring the synergistic potential in entrepreneurial university development: towards the building of a strategic framework. Ann Innov Entrep 3(1):Article 16742. http://www.tandfonline.com/doi/abs/10.3402/aie.v3i0. 17211

Goodnough K (2003) Facilitating action research in the context of science education: reflections of a university researcher. Educ Action Res 11(1):41-64

Greenwood DJ (2012) Doing and learning action research in the neo-liberal world of contemporary higher education. Action Res 10(2):115-132 
Gulbrandsen M, Aanstad S (2015) Is innovation a useful concept for arts and humanities research? Arts Humanit High Educ 14(1):9-24

Heinonen J, Poikkijoki S-A (2006) An entrepreneurial-directed approach to entrepreneurship education: mission impossible? J Manag Dev 25(1):80-94

Holm P, Jarrick A, Scott D (2015) Humanities world report 2015. Palgrave Macmillan UK, London

Jensen TL (2012) Legal aliens in entrepreneurship: an analysis of humanistic students and entrepreneurship education. Int Rev Entrep 10(2):65-90

Jensen TL (2014) A holistic person perspective in measuring entrepreneurship education impact - social entrepreneurship education at the humanities. Int J Manag Educ 12(3):349-364

Kemmis S (2009) Action research as a practice-based practice. Educational. Action Res 17(3):463-474

Kemmis S, McTaggart R, Nixon R (2014) The action research planner: doing critical participatory action research. Singapore, Springer Singapore

Kinsler K (2010) The utility of educational action research for emancipatory change. Action Res 8(2):171-189

Kirkwood J, Dwyer K, Gray B (2014) Students' reflections on the value of an entrepreneurship education. Int J Manag Educ 12(3):307-316

Kolb DA (1984) Experiential learning: experience as the source of learning and development. Prentice-Hall, Englewood Cliffs

Lee SJ, Ngo TH (2011) Riccardo Viale and Henry Etzkowitz (eds): the capitalization of knowledge: a Triple Helix of university-industry-government: Edward Elgar, 2010, p 351 ISBN: 978-1-84844-114-9. Higher Education

Leitch R, Day C (2000) Action research and reflective practice: towards a holistic view. Educ Action Res 8(1):179-193

Mann SJ (2008) Study, power and the university : the institution and its effects on learning, McGraw-hill education

Matlay H (2006) Researching entrepreneurship and education. Educ Train 48(8/9):704-718

McNiff J (2013) Action research: principles and practice. Routledge, New York

Peters J (2004) Teachers engaging in action research: challenging some assumptions. Educ Action Res 12(4):535-556

Phillips R, Hollingsworth S (2005) From curriculum to activism: a graduate degree program in literacy to develop teachers as leaders for equity through action research. Educ Action Res 13(1):85-102

Ramstad E (2008) Collaborative knowledge production model in the field of organizational development. Educ Action Res 16(2):261-278

Ranga M, Etzkowitz H (2013) Triple helix systems: an analytical framework for innovation policy and practice in the knowledge society. Ind High Educ 27(4):237-262

Sam C, van der Sijde P (2014) Understanding the concept of the entrepreneurial university from the perspective of higher education models. High Educ 68(6):891-908

Scharmer CO and K Käufer (2000) Universities as the birthplace for the creating human being. Retrieved 04-28-2016, from http://www.ottoscharmer.com/sites/default/files/2000_Uni21us.pdf

Sexton M, Lu S-L (2009) The challenges of creating actionable knowledge: an action research perspective. Constr Manag Econ 27(7):683-694

Shattock M (2009) Entrepreneurialism in universities and the knowledge economy: diversification and organizational change in European higher education. Society for Research into Higher Education \& Open University Press, New York

Smith AJ, Collins LA, Hannon PD (2006) Embedding new entrepreneurship programmes in UK higher education institutions. Educ Train 48(8/9):555-567

Smith D (1999) Burton R. Clark 1998. Creating entrepreneurial universities: organizational pathways of transformation. High Educ 38(3):373-374

Somekh B, Zeichner K (2009) Action research for educational reform: remodelling action research theories and practices in local contexts. Educ Action Res 17(1):5-21

Staniforth D, Harland T (2003) Reflection on practice: collaborative action research for new academics. Educ Action Res 11(1):79-92

Taylor A, Puchner LD, Powell MB, Harris V, Marshall R (2012) Reconceiving with action research: working within and across communities of practice in a university/community college collaborative venture. Educ Action Res 20(3):333

Taylor P, Pettit J (2007) Learning and teaching participation through action research: experiences from an innovative masters programme. Action Res 5(3):231-247

Townsend A, Thomson P (2015) Bringing installation art to reconnaissance to share values and generate action. Educ Action Res 23(1):36

Vince R (1998) Behind and beyond Kolb's learning cycle. J Manag Educ 22(3):304-319

Walton J (2011) A living theory approach to teaching in higher education. Educ Action Res 19(4):567-578

\section{Submit your manuscript to a SpringerOpen ${ }^{\circ}$ journal and benefit from:}

- Convenient online submission

- Rigorous peer review

Open access: articles freely available online

- High visibility within the field

- Retaining the copyright to your article

Submit your next manuscript at $>$ springeropen.com 